\title{
EVERYDAY ENCOUNTERS WITH NATURE: STUDENTS' PERCEPTIONS AND USE OF UNIVERSITY CAMPUS GREEN SPACES
}

\author{
Janet Speake, * Sally Edmondson, Haq Nawaz \\ Department of Geography, Liverpool Hope University, Liverpool, UK
}

\begin{abstract}
Green spaces are an integral part of many university campuses. Universities with attractive green space areas often highlight these as attributes which contribute positively to the student experience and the image of the university. This study's survey of students at Liverpool Hope University reveals insights about students' perceptions and use of campus green spaces. The vast majority of students both use and appreciate green spaces, and consider them important for the image of the university and as an essential component of the campus environment. The aesthetic qualities of the campus and its design and management style, influence perceptions and use of its green spaces with formal, manicured gardens and lawns being much preferred over more naturalistic areas. We show that a university campus needs multiple forms of green spaces to satisfy the needs of a diversity of student users, and consider the implications for a university's green space development.
\end{abstract}

Key words: Liverpool Hope University, Green spaces, Perception, Student use, Formal gardens, Naturalistic areas.

Article Info: Manuscript Received: January 28, 2013; Revised: April 15, 2013; Accepted: April 30, 2013; Online: May $25,2013$.

\section{Introduction}

Perhaps surprisingly, academics know very little of the environments in which they and their students, spend so much time. There have been few studies of how students actually encounter, perceive, evaluate and use campus green spaces in their everyday lives. Our paper therefore seeks to start to redress this by taking an in-depth look into student uses and perceptions of the green spaces of a university campus. We investigate the nature of the variables which may influence use and perceptions of these spaces and subsequently consider the wider implications of these findings.

Within the context of this research, we explore elements of the material (the university campus green environment) and non-material (exemplified by student perceptions) in the setting of the locale (Hope Park campus) to discover more about how students respond and react to their university's green spaces. In turn, this raises issues which have implications at broader scalar levels (for the

\footnotetext{
* Corresponding author:

Address: Department of Geography, Liverpool Hope University,

Hope Park, Liverpool L16 9JD, UK

Telephone: +44(o)151 2913594

Email: speakej@hope.ac.uk
}

university and beyond) such as campus design (Abu Ghazzeh, 1999) the campus as public space (Gumprecht, 2007), campus green spaces and quality of life (McFarland et al., 2008). Gumprecht (2007: 96) asserts that university campuses in their entities may be seen as places 'apart' from the wider world and designed to emulate nature and be 'beautiful and uplifting'. He also maintains that campuses are intended to influence and also to serve practical purposes in encouraging student recruitment and funding. Griffith (1994) observed that students' choice of a higher education institution often depends upon their perception of a campus. During research into student success, Walsh et al., (2009) found that the Hope Park campus environment was a significant positive factor in enhancing their experience of academic life (unpublished data). With reference to the student experience, Gumprecht (2007) reports that attractive and lively campuses create memories and build loyalty among students. Green space is intrinsic to the total material fabric of many university campuses and helps set the context for what the campus (as landscape) is, means and does.

The emergent literature on the use and perceptions of university green spaces by different stakeholders (for example by Abu-Ghazzeh, 1999) are 
situated within a broad range of studies on green spaces (i.e. outdoor spaces which contain a significant amount of vegetation). These studies explore the role of green spaces in defining communities, providing opportunities for relaxation, recreation and social interaction (Woolley, 2003). Green spaces can be seen to foster both economic benefits (Woolley, 2003); health (Frumkin, 2001) and ecological benefits (Gilbert, 1989; Alvey, 2006, Gill et al., 2007).

Green spaces are also reported in terms of resultant effects on perceptions and behaviours (Bonnes et al., 2011; Sanesi and Chiarello, 2006; Swanwick et al., 2003). Diminishing urban green spaces limits the opportunity for students to experience nature and learn about the environment. It is therefore important to understand how the campus environment contributes to student life and students' connection with nature, particularly with green spaces in their immediate surroundings. People and green spaces are tied by interconnectivities which can be premised in affective and emotional responses and ultimately reflected in people's perceptions of their environment and their articulation of them.

Inherently, as Schiffman and Kanuk (1987) have observed, 'perception' means to become aware of something using external clues, or the process through which individuals see the world around them. In terms of understanding places, spaces and also their use, it is helpful to consider perceptual dimensions and to explore, for example, users' perceptions of places and preferences for places and landscape styles (Özgüner et al., 2006, van den Berg and van Winsum-Westra, 2010, Zheng et al., 2011). Bonnes et al. (2011) contend that the exploration of green space, place and perception provides insights into human-nature integration. They also highlight the importance of understanding place-specific experience in urban green areas through self-reported perception of use and quality of such space. The predominant positive experiences of green space are associated with contact with nature and opportunities for social interaction (Burgess et al., 1988) contrast with more negative ones linked to fear and insecurity (Herzog and Flynn-Smith, 2001). Bonnes et al. (2011) have further explored the socialpsychological factors contributing to people's rather ambivalent attitudes towards green space and have noted that there are still gaps in our understanding of why people use spaces in the way they do.

Abu-Ghazzeh (1999) and McFarland et al. (2008) have integrated perception overtly into their studies of campus green space, with Abu-Ghazzeh (1999) noting that perception of a place or place meaning can comprise three types of knowledge, about the place, its affective quality, and behaviour that occurs there. Such observations illustrate the need to explore further the interconnectivities between the material and non-material traces within campus green spaces to better understand their nature and this is what this research project seeks to do.

\section{Encountering campus green spaces}

Within the context of exploring material and nonmaterial affective and behavioural interconnectivities of campus green spaces, the main aim of this research was to find out student perceptions of green spaces and their use of them within the setting of the university campus environment at Hope Park (the main campus of Liverpool Hope University). Its objectives specifically sought to find out how students use campus green spaces, their awareness of, and satisfaction with, the quality and quantity of these spaces, their most and least favourite areas on campus, and their ideas on how to improve green spaces. A questionnaire was used to provide both quantitative and qualitative data, this combination being deemed most appropriate to gain deeper insights into phenomena such as perceptions, feelings and emotions. Like Abu-Ghazzeh (1999), this research explored both spatial and behavioural dimensions of student interactions with, and space use in, their immediate (green) campus environment.

In the northwest of England, U.K., Liverpool Hope University has 7,800 students in four faculties; Arts and Humanities, Business and Computer Science, Education, and Sciences and Social Sciences. Hope Park, is an attractive, landscaped campus in a suburban setting 6.5 kilometres from Liverpool city centre, described by the university as 'a mini educational village with places to live, work, study, eat and relax' and 'beautiful surroundings'. It was selected as the case study site because of its stated image as a 'green campus' and as a hub of activities that serves not only students and staff, but also people from the surrounding residential area. Approximately $40 \%$ of the campus area is green space comprising formal landscaped gardens within which the university buildings are set. In addition, there are a number of informal naturalistic areas of woodland, scrub and long grass, these areas being mostly around the fringes of the campus. The sports areas comprise a rugby and a football pitch, and a floodlit all weather pitch area (see Figure 1).

A three page questionnaire was developed containing both open-ended and closed questions. Those relating to evaluations of cleanliness/tidiness, maintenance and management, appearance of green space, and the role of the campus green spaces in the image of the university used the Likert scale. 


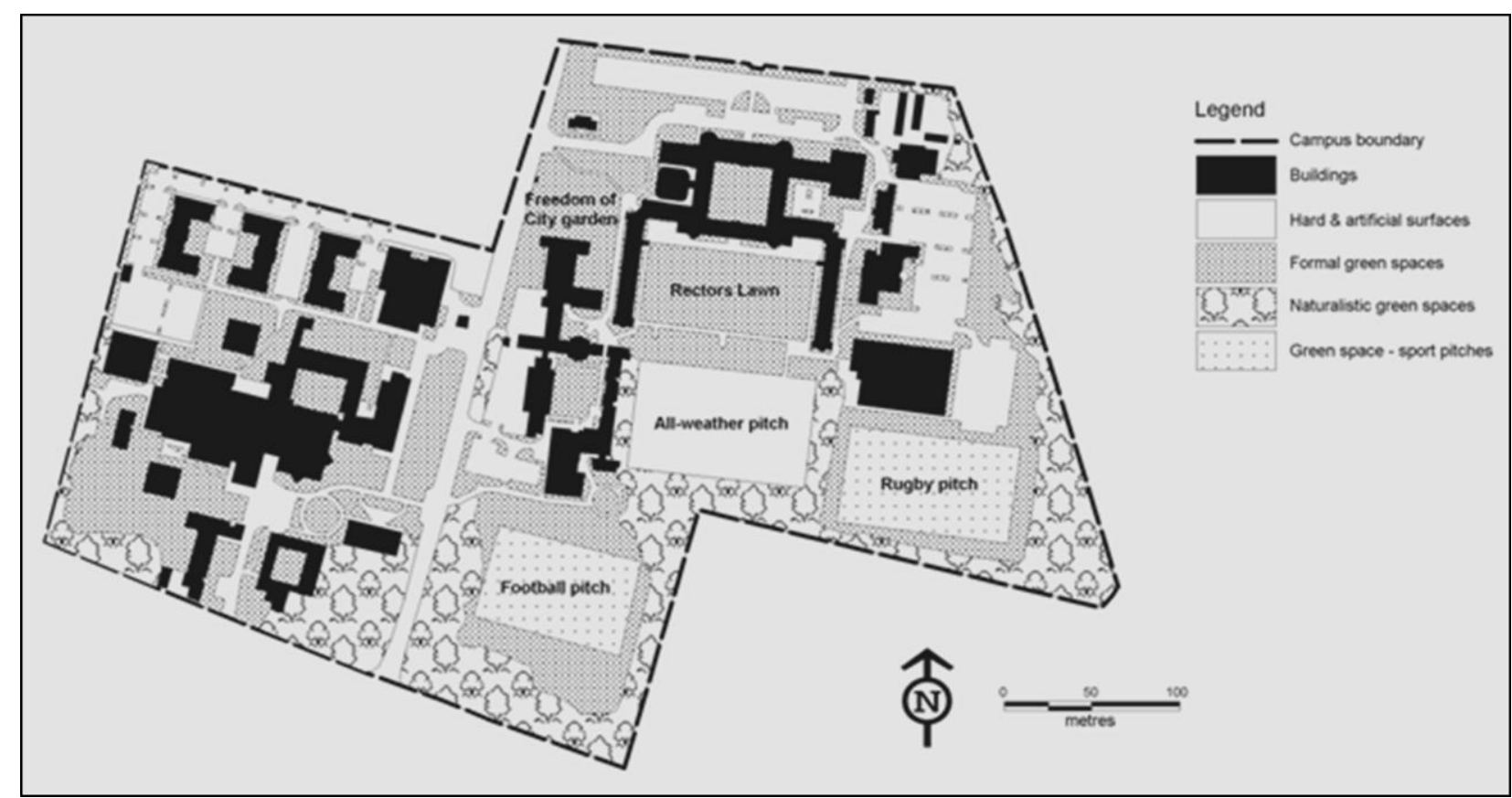

Figure 1. Hope Park, Liverpool Hope University main campus

Seeking to determine perceptions and use of green spaces at Hope Park and factors influencing them, the questions were divided into five sections, each with its own focus:

1. The demographics of the respondents.

2. Students' awareness and their use of campus green spaces.

3. Students' most and least favoured areas and the reasons for these choices. Students were provided with a campus map to facilitate their selection.

4. Students' perceptions of quantity and quality of the campus green spaces.

5. The importance, quality, area, management and cleanliness/tidiness of green spaces, their significance for the image of the university and suggestions for further improvement.

Systematic sampling of the student population by face-to-face interview with every fifth person who passed by the interviewer outside the university library entrance in 2009 provided a sample of 205 respondents, all of whom were studying at Liverpool Hope University. This may be considered to be representative of the university as a whole. No distinction was made between whether the student respondents were entering or leaving the library, although in retrospect it would have been interesting find out if students may have a different view of green spaces according to whether they were entering or leaving the library.

The main variables were perceptions and use of green spaces, gender and age, education, and the course being studied. Statistical analyses used SPSS (version 16) software. Data from open-ended questions were first categorised on the basis of key words (Strauss and Corbin, 1998) and then coded for analysis. All associations directly related to our objectives were analysed using the chi-square test with 0.05 significance levels.

Data analysis indicated that no references at all were made to the campus's extensive naturalistic areas so in order to explore possible reasons for this in some detail a focus group was convened comprising 7 postgraduate students taking the MSc in Environmental Management programme at Liverpool Hope. These students were specifically targeted because of the advanced environmental focus of their academic study. The focus group participants' observations were interpreted using thematic analysis and the key messages from this are outlined in the results.

\section{Student perceptions and uses of green space}

By presenting the results in the order outlined in the methods section i.e. socio-demographic characteristics of the students, their awareness and use of the campus green spaces, perceptions of the quantity and quality of the spaces, the context is set for exploring their favourite (preferred) spaces and use behaviours within the campus locale.

\section{Respondents' characteristics}

The 205 respondents comprised 115 (56\%) females and 90 (44\%) males, 110 (54\%) of whom were undergraduate and 95 (46\%) postgraduate students. Ages ranged from 20 and under, to over 40 , with the majority (51\%) in the $21-25$ age range. Students from 
all faculties took part, but largest faction (45\%) was from education.

\section{Respondents' familiarity with term 'green spaces'}

More than half of the respondents (6o\%) claimed that they were familiar with the term 'green spaces'. A significant relationship was found between education levels (undergraduate or postgraduate) and familiarity with the term green spaces $\left(\chi^{2}=7.46, \mathrm{df} 1\right.$, $p<0.05$,$) . However, there was no significant$ relationship between respondents' faculty and familiarity with the term. A significant relationship was also observed between gender and familiarity with the term $\left(\chi^{2}=4.74\right.$, df $\left.1, p<0.05\right)$, males $(69 \%)$ being more familiar with term than females (54\%) and also between age of respondent and familiarity with the term $\left(\chi^{2}=16.88, \mathrm{df}_{5}, p<0.05\right)$ (see Figure 2$)$.

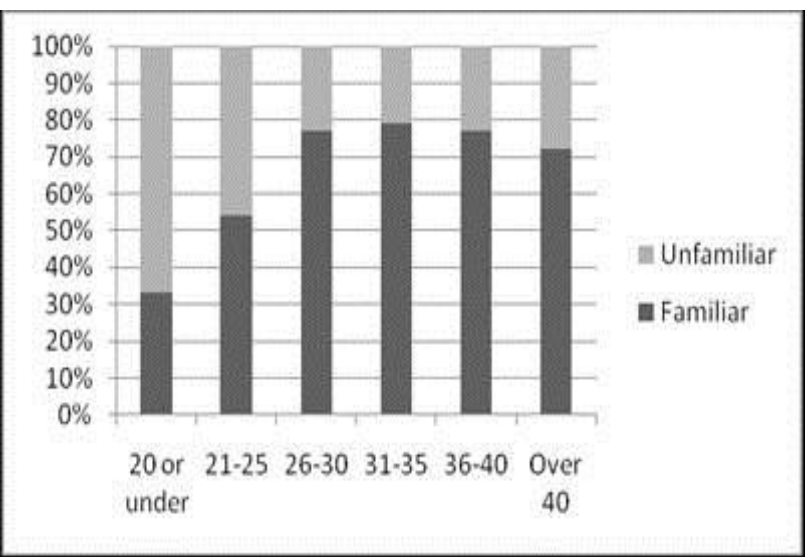

Figure 2. Respondent's age and familiarity with the term green spaces

\section{Respondents' awareness and use of campus green} spaces at Hope Park

The majority $(82 \%)$ of respondents stated that they were aware of the campus green spaces, but only $53 \%$ claimed to be using them. A significant relationship was observed between education levels of respondents and awareness of campus green spaces $\left(\chi^{2}=7.25\right.$, df $\left.1, p<0.05\right)$, undergraduate students being more aware than postgraduates. Only $11 \%$ of the undergraduate students stated they were not aware of campus green spaces but more than double the proportion of postgraduates have this response. Gender, age and faculty of the respondents showed no significant relationships with stated awareness of campus green spaces, but a significant association was found between gender and time spent outdoors on campus $\left(\chi^{2}=14.45\right.$, df $4, p<0.05$, Figure 3). Males were found to spend more time outdoors on campus than females, the modes being '1-3 times weekly' for males, and 'rarely' for females.
The age and faculties of respondents were not significantly related to the time spent outdoors on campus.

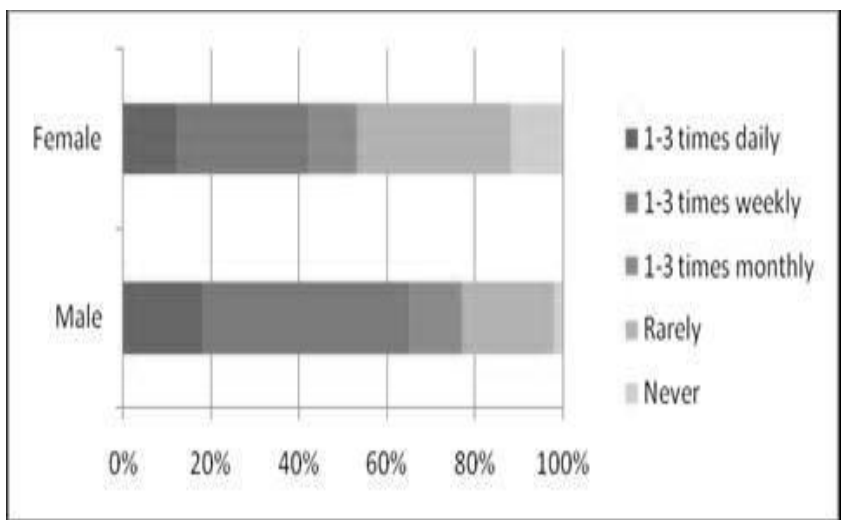

Figure 3. Gender and time spent outdoors on campus

Respondents' awareness of campus green spaces was significantly related to the use of these spaces $\left(\chi^{2}\right.$ = 27.06, df 1, $p<0$.05), Unsurprisingly students who stated awareness of campus green spaces were using them more than those claiming they were unaware.

The use of campus green spaces for social purposes was significantly related to education levels $\left(\chi^{2}=7.75, \mathrm{df} 1, p<0.05\right)$ and gender $\left(\chi^{2}=5.99, \mathrm{df} 1, p<\right.$ 0.05. see Figure 4). Undergraduate students use campus green spaces for social purposes more than postgraduate students, and females more than males. Social functions of the campus are described by students as 'simply for socialising', but more specifically as 'meeting points', 'waiting for classes' and 'chatting with friends'. These functions indicate that green spaces close to buildings, either learning or living spaces, are likely to be heavily used. This matches with convenience also being given as a basis for selecting favourite areas, students quoting 'near classes', 'near library', and 'available benches' as reasons.

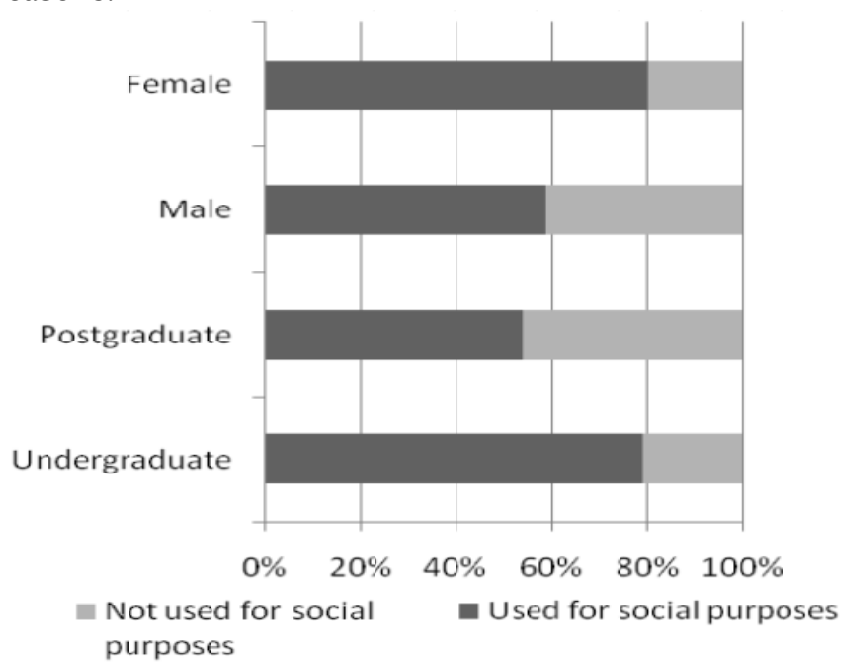

Figure 4. Respondents' use of campus green spaces for social purposes 
Similarly, gender was significantly related to use of campus green spaces for sport $\left(\chi^{2}=7.66, \mathrm{df} 1, p<\right.$ 0.05), males using for sport more than females. Students used campus green spaces for other purposes including study, relaxation and lunch, but no significant relationship with these uses was found with gender, education, age and faculty of respondents. Interestingly, the majority of students $(84 \%)$ were using campus green spaces for relaxation, this use not being related to students' age, gender, education or faculty.

\section{Students' perception of quantity and quality of campus green spaces}

A significant relationship was observed between students' perception of quantity of campus green spaces (categorised as $25 \%$ or under, $26-50 \%, 51-$ $75 \%$, over $75 \%$, with $40 \%$ being the actual value) and their awareness $\left(\chi^{2}=30.196, \mathrm{df} 3, p<0.05\right)$. Of students who stated awareness of campus green spaces , the majority (61\%) thought accurately that the campus was $26-50 \%$ green space, but $47 \%$ of the students who claimed not to be fully aware of the campus green spaces thought they were $25 \%$ or below of the area. A similar relationship was found between use and perception of quantity of green spaces $\left(\chi^{2}=\right.$ $13.72(3) p<0.05)$, the majority of students $(64 \%)$ who use campus green spaces thought that green spaces occupied $26-50 \%$ of the campus, although $45 \%$ of those not using campus green spaces also estimated green spaces to be $26-50 \%$ of the campus. Education, gender and age were not significantly associated with this perception of quantity. The results indicate an overall student perception of a very green campus. Once students were told that the campus green spaces are approximately $40 \%$, the majority of students $(81 \%)$ thought this was enough.

Respondents were also asked to rate campus green space cleanliness and tidiness; maintenance and management; and general appearance of campus green spaces on five point scale from 'very good' to 'very poor'. Eighty percent rated cleanliness and tidiness very good and the rest rated it good; maintenance and management were rated by $72 \%$ very good, $25 \%$ good and $3 \%$ average. Similarly, general appearance of green spaces was rated by $77 \%$ very good and the remainder good. Respondents' perceptions of cleanliness and tidiness of the campus green spaces were not significantly related to age, education level and time spent outdoors on campus, but were significantly associated with gender $\left(\chi^{2}=\right.$ 10.03, $p<0.05)$, more females $(88 \%)$ rating cleanliness and tidiness as very good. Perception of management and maintenance showed no relationship with age, education, gender, use of campus green spaces and time spent on campus.

Respondents' perception of the general appearance of the campus green spaces was not significantly associated with education, age, time spent outdoors on campus and use of campus green spaces, but a relationship was observed with gender $\left(\chi^{2}=12.04, \quad p<0.05\right)$, more females (86\%) rating appearance as very good. Nobody rated the cleanliness and tidiness; maintenance and management; and general appearance of campus green spaces poor or very poor.

\section{Respondents' most and least favourite green spaces}

When the students were asked 'have you got any favourite areas on campus? $81 \%$ said 'yes'. These students were then asked to identify two favourite areas on campus and their reasons for their choice.

The most frequently selected area $34 \%$ of students) was the 'Rector's Lawn' (an area of lawn with some flowerbeds that provides the setting for the most iconic and oldest building on campus - see Figure 5) followed by the 'Freedom of the City Garden' (a parkland area of mown grassland with specimen trees - see Figure 6). Common reasons for selecting these two spaces were aesthetic value, descriptions including 'nice', 'pretty', 'looks good', 'looks perfect', 'attractive'. Other important reasons for selections related to functionality, and included relaxing, convenient, place to eat and drink, social, good for study and sports. A number of these reasons were also given for the selection of 'Rector's Lawn' showing that it acts as a multifunctional green space. Interestingly, no students selected any of the naturalistic areas (see Figure 7) as their favourites. Some students gave 'natural look' as a reason for selecting 'Rectors Lawn' and 'Freedom of the City Garden' despite these areas being amongst the most formal and therefore unnatural green spaces on campus.

Age, education and faculty of respondents were not significantly related to students' favourite areas, but a significant association was observed with gender $\left(\chi^{2}=20.43\right.$ (10) $\left.p<0.05\right)$, males selecting sports fields more than females.

Only $8 \%$ of respondents indicated that they had a least favourite area on campus. The majority of these selected car parks as least favourite, areas that are not in fact green spaces. Other areas selected were 1. 'Front of Gateway Building' (a formal area of lawn with fountain and surrounding flower beds), the reason being that it is artificial rather than natural in appearance, 2 . the Lecture Theatre area because of the lack of greenery. 3 . the football and rugby pitches because they tend to be muddy and too busy. 


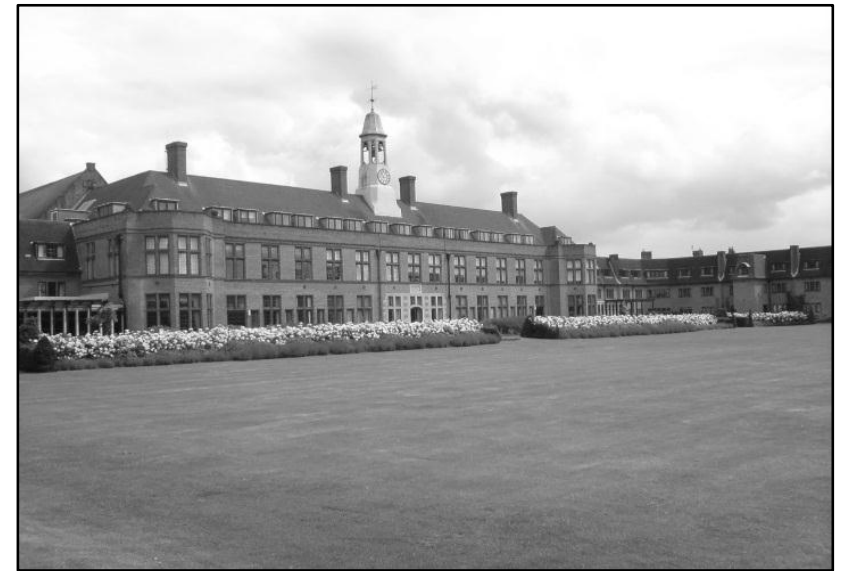

Figure 5. Rector's Lawn, Hope Park campus

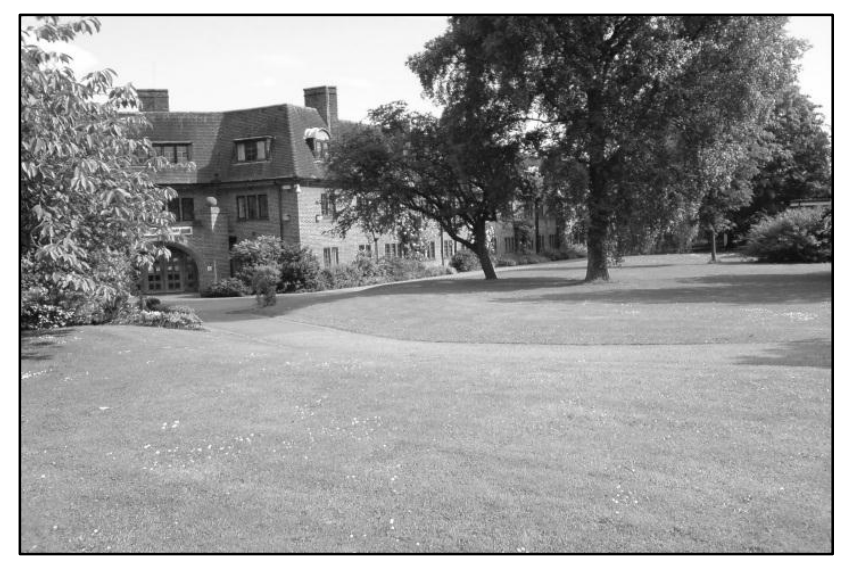

Figure 6. Freedom of the City Garden, Hope Park campus

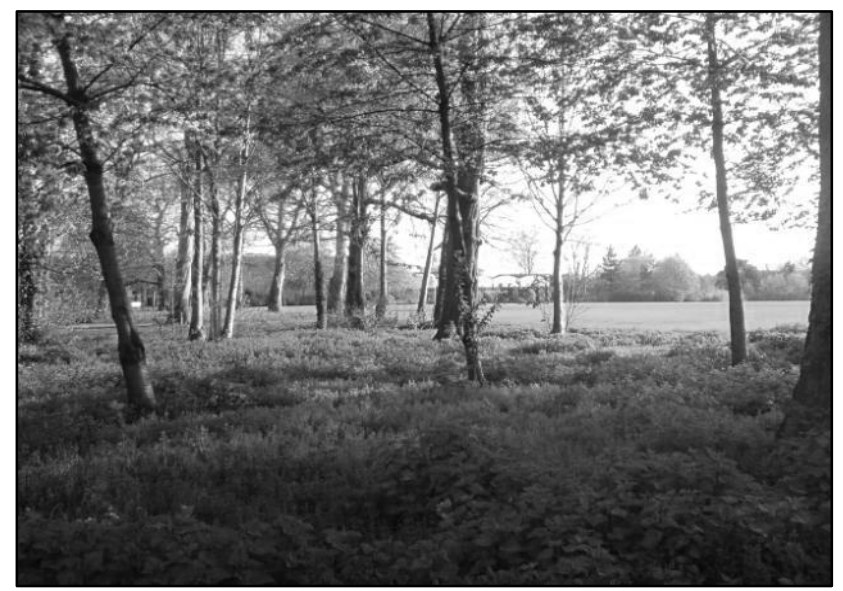

Figure 7. Naturalistic area, Hope Park campus

Respondents' suggestions for further improvement of campus green spaces

Fifty-one percent of respondents did not give any suggestions for further improvement, but said that campus green spaces had a high standard which could not be enhanced. However, $49 \%$ gave some suggestions which included adding more benches, providing shelter for bad weather conditions, planting seasonal flowers to increase aesthetic value, more trees and shrubs, more fountains and addition of signage. No respondents considered improved sustainability of management, and only one suggested encouragement of wildlife.

\section{Importance of green spaces for the image of the university}

Seventy-seven percent of respondents believed that campus green spaces are very important for the image of the university, $20 \%$ said important, and $3 \%$ unimportant. This was not significantly related to education levels, age, gender and faculty of respondents, but was significantly associated with use of campus green spaces $\left(\chi^{2}=8.11, \mathrm{df} 2, p<0.05\right)$ and time spent outdoors on campus $\left(\chi^{2}=40.27\right.$, df $8, p<$ $0.05)$. Those students who used campus green spaces or spent some times outdoor on campus strongly believed that they were very important for the image of the university. Interestingly, those students (3\%) who stated that campus green spaces were unimportant did not use them.

\section{Focus group observations}

The small focus group was convened after the questionnaire survey had been conducted to explore further some of the key issues raised by it. Principally, the ensuing discussion elicited emotive responses on the value of various types of green space. The participants emphasised the importance of the 'Rector's Lawn' as an important setting for the most historic building on campus, commenting on the effective juxtaposition of buildings and formal green gardens, describing the assemblage as 'majestic'. In contrast the focus group participants indicated the lack of any signage relating to the naturalistic areas as being significant in students' lack of awareness of, and their failure to cherish, them. They felt strongly that the lack of formally identified pathways or routes through these areas was also significant in them being 'undiscovered' and undervalued. They felt certain that provision of signs, interpretation, and paths would encourage both use and appreciation.

\section{Discussion and reflections}

The results revealed some interesting insights into how university students view, and use, green space surroundings on campus. Student awareness of green spaces in general, and on campus, is a contributory factor in influencing their perceptions of, and responses to, them. These observations concur with previous research showing that familiarity with, and awareness of, a particular place/space play an 
important role in influencing individual perceptions and use of it (Gobster et al., 2007) Increased familiarity of older and postgraduate students with the term 'green spaces' may be linked to their knowledge of a greater range of concepts compared to younger and undergraduate students (Clifton et al., 1996), and their greater experience of the value of green spaces (Ahmed and Hassan, 2003). That more male respondents than females were using green spaces for sport may influence their positive response to familiarity with the term green spaces, and possibly suggests a biased interpretation based on their regular use. Their embodied, actual physical contact with soil and grass emphasises the 'real' materiality of the green space, and would be the same for females engaging in sports such as football and rugby; this requires further investigation.

Although awareness of green spaces was reported to be high, only approximately half of students were actually using them. In accordance with LaFargue (2004) and Gobster et al. (2007) we found that awareness was positively associated with level of use of green spaces.

Good quality and aesthetics are also known to be important positive influences on greenspace use (Bradley and Millward, 1986; Abu-Ghazzeh, 1999; Korpela et al., 2001; van Herzele and Wiedemann, 2003 and Giles-Corti et al. 2005), however in this case study all respondents perceived the campus to be of very good or good quality, thus there was no disincentive to use the campus for reasons of poor quality.

The predominant purposes for green space use were relaxing and socialising, thereby concurring with Ulrich and Addoms (1981) and Gearin and Kahle (2006). Findings of Ulrich et al. (1991), LaFargue (2004), Jim and Chen (2006), and Kahn et al. (2008) suggest that this use of green spaces may be important for stress reduction. Students reported using green spaces on campus as meeting places, and social space can be important for increased social contact and reduced loneliness (Dyment and Bell, 2008; Maas et al., 2009). Different kinds of academic pressure are a source of stress to some students (Misra and McKean, 20oo) and may prevent them from having a good campus experience (Nathan, 2005).

Personal characteristics such as gender and educational levels are known to influence the use of green spaces (Abu-Ghazzeh, 1999; Dunnett et al., 2002; Sanesi and Chiarello, 2006; McFarland et al., 20o8) and were found to do so in this study. Overall, males spent more time using green spaces than females, in line with the trend found by Dunnett et al. (2002) for city parks. We found that females like green spaces more for social purposes while males for sports. Although this may not be the case in all instances, it does exemplify the need for multifunctional spaces for a diversity of users. More males than females selected sports fields as their favourite areas, which may relate to observations made by Coakley and White (1992) and Greendorfer (1993) that generally sport is more of a priority for young men than women. However, gender difference was not a factor in selection of any other favourite areas, choice possibly being mainly associated with restorative values (Purcell et al., 2001).

Location or proximity is another important determinant of use of green spaces (van Herzele and Wiedemann, 2003; Giles-Corti et al., 2005). On green campuses students have the immediate juxtaposition of green spaces with their learning and living environments. In this study, the majority of students mentioned using green spaces adjacent to their classrooms or most used buildings, utilising them for meeting up and waiting for classes. Our results show clearly that students do not use the green periphery of the campus, and that their responses focussed on green spaces immediately surrounding university buildings. Schipperijn et al. (2010) found that size of green spaces rather than distance was the main factor influencing selection of sites used. On Hope Park, the wooded, naturalistic areas are both larger and more distant (from buildings) than the selected favourite areas. Our results therefore suggest that, within the campus, size is not significant.

The majority of the students $(68 \%)$ thought that green spaces occupied 30-60 \% of the campus, an accurate or over- estimation, showing the perceived prominence of green areas on site. This may be due to the design and layout of the campus, as Forsyth (2003) showed, well designed green spaces can look much larger than their actual sizes.

Overwhelmingly, students reported that cleanliness, tidiness, management and maintenance of campus green spaces were good. Both poorly maintained and highly manicured green spaces are known to be negatively perceived, the latter potentially reducing freedom for users (Coeterier, 1996). This might be one of the reasons why a few students selected the very formal gardens of the university main entrance as a least favourite area and cited that it looked more artificial than natural.

Females rated cleanliness/tidiness and general appearance more favourably than males, which may in part be because males were using sports fields more, finding them sometimes muddy and dog fouled. The clear consensus we found on the high quality of the campus is in line with Coeterier (1996) who observed that whilst people may disagree on the use of green spaces, they generally agree on landscape qualities.

The majority of respondents selected 'Rector's Lawn' as a favourite area, the dominant reason given 
being aesthetic value, a factor recognised by AbuGhazzeh (1999), Van Herzele and Wiedemann (2003) and Giles-Corti et al. (2005). Aesthetic value was important in the selection of the most popular space on the campus. Attractiveness and aesthetic value of green spaces have been shown to depend upon the diversity of species (Lindemman-Matthies and Boss, 2008; Irvine et al., 2009) which may be one of the reasons that students suggested more flowers, trees and shrubs for improvement of this space.

A prominent outcome of the research was the failure of any respondent to mention the naturalistic areas (woodland, scrub and tall grassland; see Figure 1), either in their selection of favourite areas, or in the benefits arising from campus green space. This suggests that students are not aware of the ecological importance of green spaces, a point also reported by Lindemann-Matthies and Bose (2008). People's general lack of awareness of this ecological importance influences the tendency to prefer aesthetically pleasing (tamed) landscapes that clearly demonstrate investment of effort in landscape maintenance (Gobster et al., 2007; Ahmed and Hassan, 2003, van den Berg and Winsum-Westra, 2010, Zheng et al., 2011). Perception and preferences are closely linked and people will appreciate naturalistic areas and biodiversity if they know their importance (Lindemman-Matthies and Bose, 2008). Similarly poor image and negative perception will deter use of sites (Dunnett et al., 2002). Lack of information and awareness can also play an important role (Scott and Munson, 1994).

Four clear issues arise directly from students not favouring the naturalistic areas on campus. Firstly, these spaces at Hope Park are peripheral (see Figure 1) and thus will not be used as convenient meeting spaces or for social time between classes. Secondly, given the temperate climate in the UK, warm weather on campus encourages students to bask in the sun on open spaces, rather than seeking the shelter of shade from trees as shown by Nikolopoulu and Lykoudis (2007) to happen in the heat of a Mediterranean summer. Thirdly, the 'aesthetic conflict' identified by Gilbert (1989, p.312) is still an issue for both users and providers of naturalistic urban green spaces. This problem, of urban dwellers having become used to a neat and tidy environment, was identified in the early stages of the promotion of habitat creation and urban nature conservation by Gilbert (1989). That only traditional, formal, landscaped areas have been selected as favourite areas by students suggests that neither nature conservation generally, nor the importance of biodiverse, naturalistic areas in towns and cities in particular, are high on students' agendas when considering their local environment. This has serious implications for environmental education.
Finally, landscaped areas and gardens are not devoid of wildlife. This was clearly shown by the Biodiversity in Urban Gardens in Sheffield project (Thompson et al., 2003 and Thompson et al., 2004). Lawns can contain a variety of native plant species and perennial herbs and shrubs can provide nest, roost or foraging sites for animals. Students do, therefore, have contact with nature in these formal green spaces. Biodiversity can, however, be significantly enhanced by maximising the amount of naturalistic areas with high cover of native species. A rapidly increasing body of literature (for example Chiesura, 2004; Miller, 2005; Maller et al., 2006; Fuller et al., 2007) confirms that contact with nature is fundamental to health and well-being. Such promotion of biodiversity and provision for contact with nature where people live is nowhere more important than educational establishments that provide citizens for the future. There are indications in the literature of lack of awareness by both the public and students of biodiversity and its significance (Hvenegaard, 2007; Lindemann-Matthies and Bose, 2008). Thus, a shift towards a more sustainable campus should look to both enhancing biodiversity, and also signposting nature to students, as advised by Dixon et al. (2007).

Therefore, there seem to be opportunities for using green spaces (including the more naturalistic ones), to raise students' awareness about, and understanding of, ecological diversity. Provision of signage and identified paths and routes through the less intensively managed areas could assist with this as suggested by several students participating in the focus group. By breaking down reticence to venture into less 'tamed' and less accessible areas, students' experiences of green space diversity could be extended and go some way to reducing the 'aesthetic conflict' (Gilbert,1989, p.312).

Questionnaire respondents also suggested some infrastructure improvements, prominent amongst which was the provision of more seating. Seating often features as the single most important factor encouraging use of green spaces (Bradley and Millward, 1986; Shaftoe, 2008), although it should be carefully located (Shaftoe, 2008).

Most respondents overestimated the actual amount of campus green spaces, indicating their instinctive perception of the green nature of this suburban campus. The overestimation by respondents may be influenced by the configuration and character of the green spaces in relation to the hard structures on campus. Well-designed green spaces are known to look much larger than their actual size (Forsyth, 2003).

Students strongly agreed that green spaces are important for the image of the university and an essential component of the campus, and appreciated 
the green environment irrespective of their sociodemographic characteristics. The majority of students used and valued the campus green spaces indicating their role in the university campus experience. Presence and use of greenspace is likely to result in happier and more satisfied students (Lindholm, 1995) and is a facet of the space-use and affective-emotional responses nexus which we suggest warrants further research.

The campus can be the symbol of the university and is often prominent in promotional materials within the context of the overall student experience of campus and university life. A beautiful campus can significantly add to the positive image of a town or city, thus has benefits beyond the educational sphere (Gumprecht, 2007). Also, a balanced positive relationship between universities and their communities will improve the image of the city (van den Berg and Russo, 2004), this effect being enhanced by a greener, more wooded campus (Dober, 2000).

Students' choice of university critically depends upon their perception of the campus (Griffith, 1994; Groen and White, 2003). Our findings indicate some factors that positively influence students' perceptions and responses to the green infrastructure of the campus. For aesthetic, social and relaxation functions, well managed and maintained, formal, garden-style landscaping has been appreciated and valued. In recognition of this important factor, Liverpool Hope University has actively designed in maximum high quality green landscaping to the most recent phase of development of its inner-city Creative Campus.

We show that students respond positively to selected aspects of the campus, in particular the formal, manicured, garden-style greens spaces. The focus group highlighted the importance not only of the intrinsic aesthetic quality of the campus, but also the fact that it is so obviously cared for and maintained to a high standard. The design and management-style of green spaces influences students' perception and appreciation of the campus. Selection of favourite areas within the campus was not based on size, but on design, good quality, location and distance/convenience. Thus, our findings suggest that universities with limited amounts of green space on campus can significantly enhance both their image and the students' experience, by the design and management style of the small areas that they have. A large campus can, however, provide space for more naturalistic areas that are significant for biodiversity and sustainability. That these spaces are not as highly valued, is an issue for the university and also for biodiversity conservation and sustainability, and there is a strong argument for ensuring that such environmentally important spaces are promoted and interpreted to students.

\section{Conclusions}

This research highlights that both the material (such as green spaces and buildings) and non-material (like activities, performances and emotions) create connections between place and people. It demonstrates the importance of campus green spaces for students and shows that a university campus needs multiple forms of green spaces to satisfy the requirements of a diversity of student users. The vast majority of students appreciate and use green spaces, particularly the more formal and planned areas. A prominent outcome the research is that no students mention the naturalistic areas (woodland, scrub and tall grassland), either in their selection of favourite areas, or in the benefits arising from campus green space. Conceptually, this is important as it suggests that students are not aware of the ecological importance of green spaces. This general lack of ecological awareness influences the tendency to prefer the aesthetics of tamed and manicured landscapes. Students also consider green spaces to be important for the university's image and that they comprise an intrinsic element of the character of the campus.

This indicative study suggests that not only can green spaces serve as a potent symbol of a university and contribute positively to students' experience of life on campus and connectivity with locale and place identity, but also that they can provide many opportunities for improving students' awareness of local biodiversity and its management. It is clear too, that listening to student voices can inform understanding of their perceptions and opinions about the green spaces in the culture/context interface of their everyday lives, and contribute to wider discourses on how these spaces can be enhanced.

\section{Acknowledgements}

We would like to thank all the students who took part in this survey and also colleagues who have contributed creative synergies to this project.

\section{References}

Abu-Ghazzeh, TM 1999, 'Communicating behavioural research to campus design', Environment and Behavior, vol. 31, pp. 764-804.

Ahmed, MK \& Hassan, R 2003, People's perception toward value of urban green spaces in environmental development, Proceedings of XII World Forest Congress, Quebec, 
Canada, viewed on 26th January 2013, http://www.fao.org/DOCREP/ARTICLE/WFC/XII/o347B5.HTM.

Alvey, AA 2006, 'Promoting and preserving biodiversity in the urban forest', Urban Forestry and Greening, vol.5.4, pp. 195-201.

Bonnes, M, Passafaro, P \& Carrus, G 2011, 'The ambivalence of attitudes toward urban green areas: between proenvironmental worldviews and daily residential experience', Environment and Behavior, vol. 43.2, pp. 207232.

Bradley, C \& Millward, A 1986, 'Successful green space- do we know it when we see it', Landscape Research, vol.11, pp. 2-8.

Burgess, J, Harrison, CM \& Limb, M 1988, 'People, parks, and the urban green: a study of popular meanings and values for open spaces in the city', Urban Studies, vol. 25, pp. 455-473.

Chiesura, A 2004, 'The role of urban parks for the sustainable city', Landscape and Urban Planning, vol. 68, pp. 129-138.

Clifton, RA, Etchevery, E, Hasinoff, S \& Roberts, LW 1996, Measuring the cognitive domain of the quality of life of university students, Social Indicators Research, vol. 38, pp. 29-52.

Coakley, JJ \& White, A 1992, 'Making decisions: Gender and sports participations among British adolescents', Sociology of Sport Journal, vol. 9, pp. 20-35.

Coeterier, JF 1996, 'Dominant attributes in the perception and evaluation of the Dutch landscape', Landscape and Urban Planning, vol. 34, pp. 27-44.

Dixon, M, Webb, M, Cook, G \& Forster, J 2007, Biodiversity on Campus: An EAUC practical guide, Cheltenham, UK, The Environmental Association for Universities and Colleges.

Dober, RP 200o, Campus Landscape: Functions, Forms, Features, New York, John Wiley \& Sons.

Dunnett, N, Swanwick, C \& Wooley, H 2002, 'Improving urban parks, play areas and open spaces', Urban Research Report, London, DTLR.

Dyment, JE \& Bell, AC 2008, 'Our garden is colour blind, inclusive and warm: reflections on green school grounds and social inclusion', International Journal of Inclusive Education, vol. 12, pp. 169-183.

Forsyth, A 2003, People and urban green areas: perception and use, Design Center for American Urban Landscape, $\begin{array}{llll}\text { viewed } & \text { on } & 9^{\text {th }} & \text { August }\end{array}$ http://www.designcenter.umn.edu/reference ctr/publications/pdfs/db4.pdf.

Frumkin, H 2001, 'Beyond toxicity: Human health and the natural environment', American Journal of Preventative Medicine, vol. 20, pp. 234-240.

Fuller, RA, Irvine, KN, Devine-Wright, P, Warren, PH \& Gaston, K 2007, 'Psychological benefits of greenspace increase with biodiversity', Biology Letters, vol. 3, pp. 390394 .

Gearin, E \& Kahle, C, 2006, 'Teen and adult perceptions of urban green space in Los Angeles', Children, Youth and Environments, vol. 16, pp. 25-48.

Gilbert, OL 1989, 'The ecology of urban habitats', London, Chapman and Hall.

Giles-Corti, B, Broomhall, MH, Knuiman, M, Collins, C, Douglas, KNgK, Lange, A \& Donovan, RJ 2005, 'Increasing walking: How important is distance to, attractiveness, and size of public open space', American Journal of Preventive Medicine, vol. 28, pp. 169-176.

Gill, SE, Handley, JF, Ennos, AR \& Pauleit, S 2007, 'Adapting Cities for Climate Change: The role of the green infrastructure', Built Environment, vol. 33.1, pp. 115-133.

Gobster, PH, Nassauer, JI, Daniel, TC \& Fry, G 2007, 'The shared landscape: what does aesthetics have to do with ecology', Landscape Ecology, vol. 22, pp. 959-972.

Greendorfer, SL 1993, 'Gender role stereotypes and early childhood socializations', Psychology of Women Quarterly, vol. 11, pp. 327-340.

Griffith, JC 1994, 'Open space preservation: an imperative for quality campus environments', Journal of Higher Education, vol. 65, pp. 645-669.

Groen, JA \& White, MJ 2003, 'In-state versus out-of-state students: the divergence of interest between public universities and state governments', Journal of Public Economics, vol. 88, pp. 1793-1814.

Gumprecht, B 2007, 'The campus as a public space in the American college town', Journal of Historical Geography, vol. 33, pp. 72-103.

Herzog, TR \& Flynn-Smith, JA 2001, 'Preference and perceived danger as a function of the perceived curvature, length, and width of urban alleys', Environment and Behavior, vol. 33, pp. 653-666.

Hvenegaard, G 2007, 'A Novel approach to deepen understanding of undergraduates' environmental background', International Research in Geographical and Environmental Education, vol. 16, pp. 328-338.

Irvine, KN, Devine-Wright, P, Payne, SR, Fuller, RA, Painter, B \& Gaston, KJ 2009, 'Green space, soundscape and urban sustainability: an interdisciplinary, empirical study', Local Environment, vol. 14, pp. 155-172.

Jim, CY \& Chen, WY 2006, 'Recreation, amenity use and contingent valuation of urban green spaces in Guangzhou, China', Landscape and Urban Planning, vol. 75, pp. 81-96.

Kahn, PH, Friedman, B, Hagman, J, Feldman, E, Carrere, S, Severson, R, Gill, B \& Stolyar, A 2008, 'A plasma display window? The shifting baseline problem in a technologically mediated natural world', Journal of Environmental Psychology, vol. 28, pp. 192-199.

Korpela, KM, Hartig, T, Kaiser, FG \& Fuhrer, U 2001, 'Restorative experience and self-regulation in favorite places', Environment and Behavior, vol. 33, pp. 572-589.

LaFargue, L 2004, Nature is to nurture: a post occupancy evaluation of the St. Michael Health Care Center, Texarkana, TX, Master thesis, Louisiana State University, Department of Landscape Architecture, Louisiana.

Lindemann-Matthies, P \& Bose E 2008, 'How many species are there: public understanding and awareness of biodiversity in Switzerland', Human Ecology, vol. 36, pp. 731-742.

Lindholm, G 1995, 'Schoolyards: the significance of place properties to outdoors activities in schools', Environment and Behavior, vol. 27, pp. 259-293.

Maas, J, van Dillen, S M, Verheij, R A, \& Groenewegen, P P 2009, 'Social contact as a possible mechanism behind the relation between green space and health', Health and Place, vol. 15, pp. 586-595.

McFarland, AL, Waliczek, TM, Zajicek, JM 2008, 'The Relationship Between Student Use of Campus Green 
Spaces and Perceptions of Quality of Life, Horticulture Technology, vol. 18, pp. 196-319.

Maller, C, Townsend, M, Pryor, A, Brown, P \& St Leger, L 2006, 'Healthy nature healthy people: 'contact with nature' as an upstream health promotion intervention for populations', Health Promotion International, vol. 21.1, pp. 45-54.

Miller, JR 2005, 'Biodiversity conservation and the extinction of experience', Trends in Ecology and Evolution, vol. 20.8, pp. 430-434.

Misra, R \& McKean, M 200o, 'College students' academic stress and its relation to their anxiety, time management and leisure satisfaction', American Journal of Health Studies, vol. 16, pp. 41-51.

Nathan, R 2005, My Freshman Year: what a professor learned by becoming a student, New York, Cornell University Press.

Nikolopoulu, M \& Lykoudis, S 2007, 'Use of outdoor spaces and microclimate in a Mediterranean urban area', Built Environment, vol. 42.10, pp. 3691-3707.

Özgüner, H, Kendle, AD \& Bisgrove, JR 2006, 'Attitudes of landscape professionals towards naturalistic versus formal urban landscapes in the UK', Landscape and Urban Planning, vol. 81, pp. 34-45.

Purcell, T, Person, E \& Berto, R 2001, 'Why do preferences differ between scene types?', Environment and Behavior, vol.33, pp. 93-106.

Sanesi, G \& Chiarello, F 2006, 'Residents and urban green spaces: the case of Bari', Urban Forestry and Urban Greening, vol. 4, pp. 125-134.

Schiffman, L \& Kanuk, L 1987, Consumer Behavior, New Jersey, Prentice-Hall.

Schipperijn, J, Stigsdotter, UK, Randrup, TB \& Troelsen, J 2010, 'Influences on the use of urban green space- A case study in Odense, Denmark', Urban Forestry and Urban Greening, vol. 9, pp. 25-32.

Scott, D \& Munson, W 1994, 'Perceived constraints to park usage among individuals with low incomes', Journal of Park and Recreation Administration, vol. 12, pp. 79-96.

Shaftoe, H 2008 Convivial Urban Spaces: creating effective public places, London, Earthscan.
Strauss, A \& Corbin, J 1998, Basic of Qualitative Research: Techniques and procedure for developing Grounded theory, London, Sage.

Swanwick, C, Dunnett, N \& Wolley, H 2003, 'Nature, Role and Value of Green Space in Towns and Cities: An Overview', Built Environment, vol. 29, pp. 94-106.

Thompson, K, Austin, K, Smith, R, Warren, P, Angold, P \& Gaston, K 2003, 'Urban domestic gardens (I): Putting small-scale plant diversity in context', Journal of Vegetation Science, vol. 14, pp. 71-78.

Thompson, K, Hodgson, JG, Smith, RM, Warren, PH \& Gaston, KJ 2004, 'Urban domestic gardens (III): Composition and diversity of lawn floras', Journal of Vegetation Science, vol. 15, pp. 373-378.

Ulrich, RS \& Addoms, D 1981, 'Psychological and recreation benefits of a recreational park', Journal of Leisure Research, vol. 13, pp. 43-65.

Ulrich, RS, Simons, RF, Losito, BD, Fiorito, E, Miles, MA \& Zelson, M 1991, 'Stress recovery during exposure to natural and urban environments', Journal of Environmental Psychology, vol. 11, pp. 201-230.

Van den Berg, L \& Russo, AP 2004, The student city: strategic planning for student communities in EU cities, Aldershot, Ashgate.

Van den Berg, AE \& van Winsum-Westra, M 2010, 'Manicured, romantic or wild? The relation between the need for structure and preferences for garden styles', Urban Forestry and Urban Greening, vol. 9, pp. 179-186.

Van Herzele, A \& Wiedemann, T 2003, 'A monitoring tool for the provision of accessible and attractive urban green spaces', Landscape and Urban Planning, no 63, pp. 109-126. Walsh, C, Larsen, C \& Parry, D 2009, 'Academic tutors at the frontline of student support in a cohort of students succeeding in higher education', Educational Studies, vol. 35.4, pp. 405-424

Woolley, H 2003, Urban Open Spaces, Spon Publishers, London.

Zheng, B, Zhang, Y \& Chen, J 2011, Preference to home landscape: wilderness or neatness? Landscape and Urban Planning, vol. 99, pp. 1-8. 